\title{
Seasonal Changes in Home Range and Habitat Use of Elephants in Southern and North-central Provinces of Sri Lanka
}

\author{
M.S.L.R.P. Marasinghe* , N.D.K. Dayawansa ${ }^{1}$ and R.P. De Silva ${ }^{1}$ \\ Postgraduate Institute of Agriculture \\ University of Peradeniya \\ Sri Lanka
}

\begin{abstract}
Elephants generally require a large area of habitat, and usually avoid human settlements and agricultural lands. However, less protected agricultural lands such as Chenas are vulnerable during droughts where food is scarce. If available, grasslands are highly preferred by elephants, and forest lands are less preferred compared to scrub lands. According to past research, it was estimated that Sri Lankan female elephants have home ranges of about $29.6-160.7 \mathrm{~km}^{2}$. The objective of this study was to access the seasonal changes of home ranges and the habitat selection of elephants in Southern and NorthCentral Provinces of Sri Lanka. This study also attempted to estimate the size of the home range using satellite telemetry data collected for two study sites with minimum convex polygon approach. Seasonal home ranges and home range core areas were derived using 95\% and 50\% Nonparametric Kernel Utilization Distribution. The land use selection was analysed using the Jacob's Index and the expected proportional usage of habitats were calculated. The estimates were evaluated against the Bonferroni's simultaneous confidence intervals. The results identified that average size of the home range of female herds during the dry season is about $73 \mathrm{~km}^{2}$. The seasonal fluctuation of elephant home range lies within 12.12- $73.07 \mathrm{~km}^{2}$. As identified by the present study, the maximum size of the core of the home range where elephants spend more time is $25.76 \mathrm{~km}^{2}$. It suggests that preferences and spatial requirements highlighted by this study should be taken into consideration when the interventions are made on manipulation of the home range of elephants for management requirements. The geo-informatics approach used in the study could also be used effectively in implementing such interventions.
\end{abstract}

Keywords: Asian elephant, home range, seasonal habitat preference, geo-informatics

\section{INTRODUCTION}

The elephant survey conducted in 2012 suggests that, more than 5,879 wild elephants exist in Sri Lanka (Department of Wildlife Conservation, 2013). Sri Lanka holds an important position with regard to Asian elephant conservation as a country with the highest density of elephants (Fernando et al., 2011).

Elephants are highly mobile and have large home ranges (Jakson et al., 2005). Fragmentation and loss of the natural habitats of elephants (Desi, 1998) are considered to be the main cause of Human Elephant Conflict in Sri Lanka (Bandara, 2005). According to Baskaran et al. (1995) home ranges of Sri Lankan elephants are relatively small compared to that of

\footnotetext{
1 Department of Agricultural Engineering, Faculty of Agriculture, University of Peradeniya, Sri Lanka

Corresponding author: ranjandwc@gmail.com
} 
Southern India. Home ranges of Sri Lankan male elephants vary from 53.6-346 $\mathrm{km}^{2}$ and in the case of females, it ranges within $29.6-160.7 \mathrm{~km}^{2}$ (Weerakoon et al., 2003). According to Weerakoon et al. (2003) Sri Lankan elephants show a high fidelity to home ranges.

The African elephants concentrate their movement to areas where the water is available during dry season and they expand their ranges (Western et al., 1984). However, Weerakoon et al. (2003) argues that the Asian Elephants in Sri Lanka shows no distinct seasonal range differences during wet and dry seasons. The same author has also noted that there is a trend of increasing home range size with increasing fragmentation of land by the elephants inhabited in landscapes with high level of human activity (Weerakoon et al., 2003). However, in another view, the water scarcity in the dry season is considered to be one of the reasons for elephants to come out of the protected areas (Santiapillai et al., 1994). In other words, the elephants are moving out of the core area during the dry season. The escalated level of human elephant conflict during dry season justifies this view as elephants' raid human habitats mostly during dry season. However, the research suggests that monthly distribution of human elephant conflict incidents were strongly negatively correlated with rainfall, but not with the availability of water (Campos-Arceiz et al., 2009).

The occurrence of dry seasons in between the two rainy seasons is a well-recognized character for the dry zone of Sri Lanka (De Silva and Punyawardena, 2006). The main rainy season of the dry zone of Sri Lanka comes from September to December (Campos-Arceiz et al., 2009). The dry season runs from June to mid-September, with the maximum drought occurring in August and early September. In April and May, there is a shorter period of rains (Campos-Arceiz et al., 2009).

The habitat usage of elephants is influenced by many factors including vegetation quality and biomass (Natumi et al., 2005) vegetation cover, water availability (Natumi, 2002) and human disturbance in response to crop damages (De Boer and Baquete, 1998). Since the seasonality of Sri Lanka and the above mentioned factors depend on rains, the seasonality should have an impact on the movement and the habitat use of the elephants.

\section{Objectives}

In this context, the objective of this study was to examine the home ranges and to explore the seasonal changes of habitat used by two selected herds of elephants. The specific objectives of the study were;

- to examine the home range sizes and the seasonal changes of selected elephant herds using geo-informatics tools.

- to investigate the habitat selection and use patterns in the study sites.

\section{METHODOLOGY}

The study was carried out in two sites located in the North-Central and Southern Regions. Two elephant herds selected were monitored using satellite telemetry for almost 2 years from 2009 to 2011. One elephant herd was roaming in Palugasdamana, Hingurakgoda, Dambulla and the boundary of Kekirawa Divisional Secretariat Divisions (Site 1 - North-Central ) and the second heard was roaming in Lunugmavehera, Hambantota, Sooriya Wewa and Tanamalwila Divisional Secretariat Divisions (Site 2 - Southern). The location of the two 
sites is shown in Fig. 1. Location data of herd 1 was collected from 05/11/2009 to $30 / 09 / 2012$ and of herd 2 data were collected from 18/09/2009 to 30/09/2012. Data have been recorded at four hour intervals in both cases.
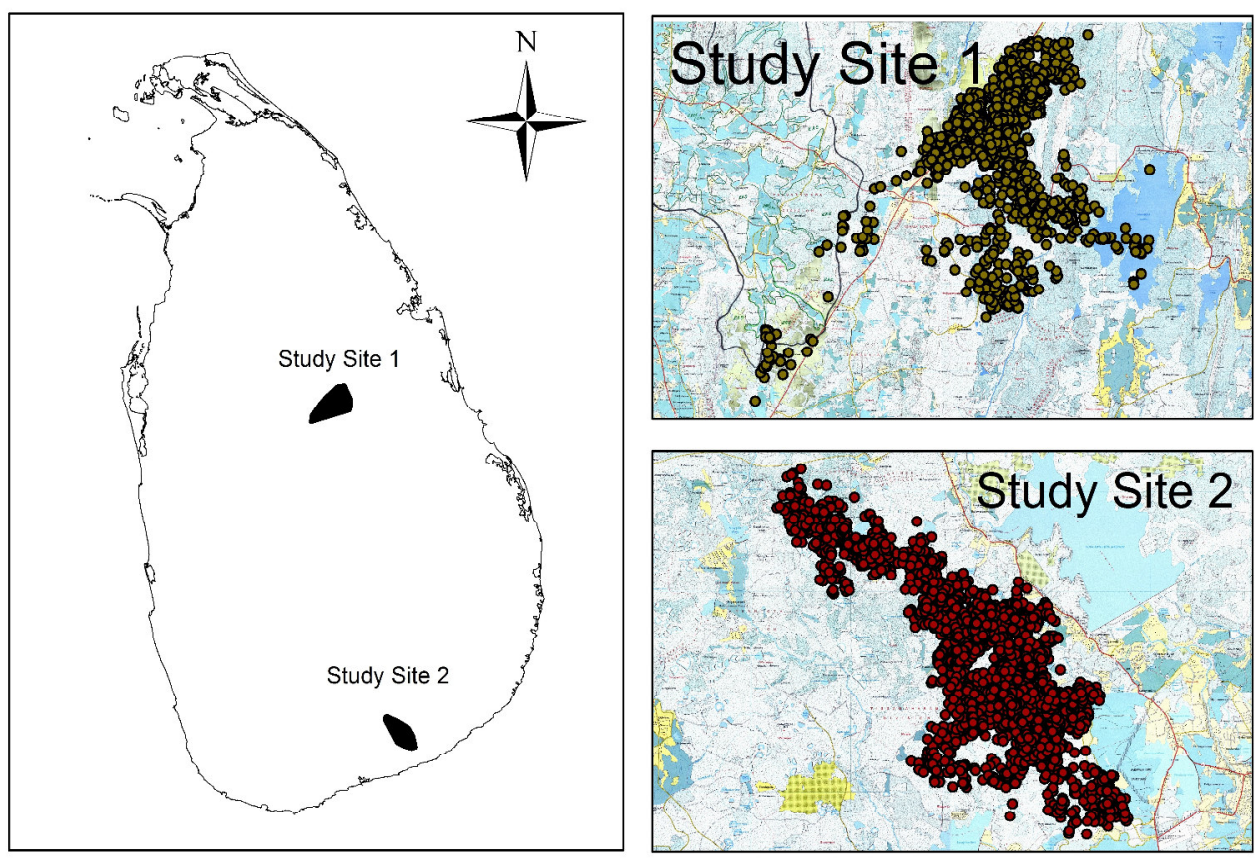

Fig.1. The study sites

\section{Range size and the seasonal spatial changes}

Using the location data set of each elephant herd, maximum area where they have moved during the study period was determined using the Minimum Convex Polygon (MCP) approach (Natumi et al., 2005). A buffer of $1000 \mathrm{~m}$ was added to the derived MCP and considered as the area of interest (AOI) for that elephant heard. Then the location data was grouped according to the dry and wet periods (Campos-Arceiz et al., 2009) of the dry zone of Sri Lanka (De Silva et al., 2006).

Table 1. Rainfall seasons of the day zone of Sri Lanka

\begin{tabular}{lcc}
\hline \multicolumn{1}{c}{ Season } & Duration & Remarks \\
\hline $1^{\text {st }}$ Dry Season & February to March & \\
$1^{\text {st }}$ Wet season & April to May & \\
$2^{\text {nd }}$ Dry Season & June to September & Acute dry season \\
$2^{\text {nd }}$ Wet Season & October to February & Main wet season \\
\hline
\end{tabular}

Source: Campos-Arceiz et al. (2009) and De Silva et al. (2006) 
Generally, the minimum convex polygon approach is used in the home range area calculations. In this approach, areas that elephants have never visited are also included. However if one needs to identify the actual area where elephants really visited, the nonparametric kernel Utilization Distribution (UD) provides more rational outcomes. Within the home range, elephants tend to spend more time in certain areas and such areas are called core areas. Such core areas could also be identified using the same approach.

The seasonal home range of each elephant herd was derived using $95 \%$ nonparametric kernel Utilization Distribution (UD) and the core area of the home range was derived using the same method at 50\% UD (Borger et al., 2006). The Least Square Cross Validation (LSCV) was used to determine the smoothing factor (Worton, 1989).

From the perspective of humans, Human-Elephant Conflict has two dimensions; human deaths and the crop/property damages. The male elephants tend to invade the human habitats as single individuals and most of the human deaths and property damages are caused by them. The females are generally move as herds and often responsible for crop damages (Arceiz et al., 2009). The study focused on the behaviour of the herds comprising females, juveniles and calves.

\section{Habitat selection and use}

The elephants are generally not restricted to legally protected areas. Hence the selection of the land use types available in the area by elephant was assessed. The digital land use data prepared by the Survey Department of Sri Lanka was used in the analysis. The land use selection was analysed using the Jacob's Index; JI (D). JI (D) is defined (Jacobs, 1974) as (r$\mathrm{p}) /(\mathrm{r}+\mathrm{p}-2 \mathrm{rp})$ where $\mathrm{r}$ is the proportion of considered land use class in the home range $(95 \%$ UD) and $\mathrm{p}$ is the proportion of that land use class in the AOI of the herd. JI (D) is a value ranging from -1 to +1 and the values $>0.3$ are considered as preferred while values $<-0.3$ are considered as avoided land use types (Kriegler et al., 1969).

The occurrence of a particular vegetation type in a space used by an animal does not necessarily indicate that it is preferred (Roux et al., 2007). Hence the habitat use preferences were evaluated using the method described by Neu et al. (1974) and Byers et al. (1984). First the area under each land use class in the $\mathrm{AOI}\left(\mathrm{AHC}_{\mathrm{AOI}}\right)$ was calculated and the relative area $\left(\mathrm{RA}_{\mathrm{AOI}}\right)$ was calculated using the formula $\mathrm{RA}_{\mathrm{AOI}}=\mathrm{AHC}_{\mathrm{AOI}} / \mathrm{A}_{\mathrm{AOI}}$. Then the expected usage $\left(U_{E}\right)$ was calculated by multiplying the total number of GPS fixes (TFX) within the AOI by the $\mathrm{RA}_{\mathrm{AOI}}\left(\mathrm{U}_{\mathrm{E}}=\mathrm{TFX}\right.$. $\left.\mathrm{RA}_{\mathrm{AOI}}\right)$. The actual usage $\left(\mathrm{U}_{\mathrm{A}}\right)$ was considered as the total number of GPS fixes within the considered habitat class $\left(\mathrm{TFX}_{\mathrm{HC}}\right)$. The expected proportional usage $\left(\mathrm{U}_{\mathrm{PE}}\right)$ and the observed proportional usage $\left(\mathrm{U}_{\mathrm{OE}}\right)$ were calculated as $\mathrm{U}_{\mathrm{PE}}=\mathrm{U}_{\mathrm{E}} / \mathrm{TFX}$ and $\mathrm{UPA}=\mathrm{U}_{\mathrm{A}} / \mathrm{TFX}$. Finally the expected usage was evaluated against the Bonferroni's (Byers et al., 1984) simultaneous confidence intervals. Chi-Square goodness of fit test was also performed on the expected and actual usage values (Byers et al., 1984).The confidence interval (CI) was calculated using Equation 1.

$$
C I=U_{P A} \mp Z_{I / 2 k} \sqrt{\frac{U_{P A}\left(1-U_{P A}\right)}{T F X}}
$$

Value of $\alpha$ is the probability at which the CI is calculated and $\mathrm{k}$ is the number of land use classes. If the CI falls below the expected proportional usage $\left(\mathrm{U}_{\mathrm{PE}}\right)$, the habitat is avoided. If 
the CI falls above the $\mathrm{U}_{\mathrm{PE}}$ the habitat is preferred. If the $\mathrm{U}_{\mathrm{PE}}$ is within the CI habitat is used according to the abundance in the area (Roux et al., 2007).

In the analysis, ABODE V5.1, a free software developed for ArcMap V10.1 by the Department of Fisheries and Wildlife Sciences of Virginia Tech University, USA was used in generating home ranges. Python scripts were used in calculating the JI (D) and CI values.

\section{RESULTS AND DISCUSSION}

\section{Home range size and seasonal spatial changes}

The area of the entire landscape where the elephant roam during the study period was 326.57 $\mathrm{km}^{2}$ in the study site 1 (North-Central Region) whereas it is only $217.03 \mathrm{~km}^{2}$ in the site 2 (Southern Region). Site 1 comprises of eight land use types including grasslands. But in study site 2, seven land use types were observed but grasslands. The seasonal home ranges and core areas were generated for four seasons for both sites as shown in Fig. 2. The calculated area of home ranges is shown in Table 2 . The seasonal home range of the site 1 elephants herd vary from 12.12 to $72.97 \mathrm{~km}^{2}$ whereas in site 2 it is ranging from 49.34 to $73.07 \mathrm{~km}^{2}$. The seasonal core area of the site 1 herd varied from 3.24 to $16.04 \mathrm{~km}^{2}$ whereas for the site 2 herd, it varied from 21.62 to $25.76 \mathrm{~km}^{2}$. The maximum size of the seasonal home range was generally shown during the dry season. In North-Central herd (site 1), the maximum seasonal home range was observed in the $2^{\text {nd }}$ Dry Season (June- Sept.). Maximum seasonal home range was observed for the Southern Region herd (Site 2) in the $1^{\text {st }}$ Dry season (Jan-Mar). Even though the total area at the dispose (the total area where the herd has explored during the study period) of site 1 herd was higher than the site 2, the seasonal home range and the seasonal core home ranges of the site 2 elephants are high. When the overall situation in both sites is considered, elephants were roaming in area less than $73 \mathrm{~km}^{2}$. However, in both cases, they have concentrated in an area of $25.76 \mathrm{~km}^{2}$ at most of the time.

Table 2. Variation of the extent of seasonal home ranges

\begin{tabular}{|c|c|c|c|c|c|c|}
\hline \multirow[b]{2}{*}{ Season } & \multicolumn{3}{|c|}{ North-Central Region (Site 1) } & \multicolumn{3}{|c|}{ Southern Region (Site 2) } \\
\hline & $\begin{array}{c}\text { Area } \\
\text { Available }\end{array}$ & $\begin{array}{c}\text { Seasonal } \\
\text { Home } \\
\text { Range }\end{array}$ & $\begin{array}{l}\text { Core } \\
\text { Home } \\
\text { Range } \\
\end{array}$ & $\begin{array}{c}\text { Area } \\
\text { Available }\end{array}$ & $\begin{array}{c}\text { Seasonal } \\
\text { Home } \\
\text { Range } \\
\end{array}$ & $\begin{array}{l}\text { Core } \\
\text { Home } \\
\text { Range } \\
\end{array}$ \\
\hline $\begin{array}{l}1^{\text {st }} \text { Dry } \\
\text { (Feb-Mar) }\end{array}$ & 326.57 & 12.12 & 3.24 & 217.03 & 73.07 & 23.76 \\
\hline $\begin{array}{l}1^{\text {st }} \text { Wet } \\
\text { (Apr-May) }\end{array}$ & 326.57 & 30.78 & 8.12 & 217.03 & 65.99 & 21.62 \\
\hline $\begin{array}{l}2^{\text {nd }} \text { Dry } \\
\text { (Jun-Sep) }\end{array}$ & 326.57 & 72.97 & 16.04 & 217.03 & 49.34 & 13.64 \\
\hline $\begin{array}{l}2^{\text {nd }} \text { Wet } \\
\text { (Oct-Jan) }\end{array}$ & 326.57 & 33.25 & 7.71 & 217.03 & 71.82 & 25.76 \\
\hline
\end{tabular}

*All areas are in $\mathrm{km}^{2}$ 


\section{Habitat selection and use}

In the study site 1 grasslands were available but not in the study site 2 . The grassland available in site 1 falls within Hurulu Forest Reserve. The calculated Jacob's Indexes for each land use type for both study sites are shown in Table 3 and Table 5. The preference and avoidance derived from Jacob's index is shown in Table 4 and Table 6.

In site 1, human habitats and paddy cultivations have been avoided by the elephants. Forest lands and the Scrub lands were indifferent. Chenas have been avoided in the dry season and indifferently used during rainy seasons. However in the overall picture, Chenas have been avoided by the elephants. Grasslands were preferred in dry seasons and indifferently preferred in rainy seasons. Rocks were generally indifferent but in dry seasons they have avoided such areas. Water bodies were mostly avoided except in the acute dry seasons but have been visited for a shorter period for drinking and wallowing purposes.

Table 3. Jacob's Index values for the $1^{\text {st }}$ site

\begin{tabular}{lcccr}
\hline \multicolumn{1}{c}{ Habitat } & $\begin{array}{c}\mathbf{1}^{\text {st }} \text { Dry } \\
\text { Season }\end{array}$ & $\begin{array}{c}\mathbf{1}^{\text {st }} \text { Rainy } \\
\text { Season }\end{array}$ & $\begin{array}{l}\mathbf{2}^{\text {nd }} \text { Dry } \\
\text { Season }\end{array}$ & $\begin{array}{c}\mathbf{2}^{\text {nd }} \text { Rainy } \\
\text { Season }\end{array}$ \\
\hline $\begin{array}{l}\text { Chena } \text { and Rain Fed } \\
\text { Vegetables }\end{array}$ & -0.9186 & -0.1496 & -0.8476 & -0.2283 \\
Forest & & & & \\
Grassland & -0.2480 & -0.0234 & 0.2209 & 0.2029 \\
Human Habitats & 0.9970 & -1.0000 & 0.4549 & -1.0000 \\
Paddy Cultivations & -1.0000 & -0.9498 & -0.8860 & -0.3154 \\
Rocks & -1.0000 & -0.6975 & -0.9187 & -0.6437 \\
Scrub Land & -1.0000 & 0.2812 & -0.6977 & -0.2000 \\
Water bodies & -0.0612 & 0.2911 & 0.2221 & 0.0663 \\
\hline & -1.0000 & -0.9254 & -0.0454 & -0.4975 \\
\hline
\end{tabular}

Table 4. Selection of habitats by elephants in the $1^{\text {st }}$ site

\begin{tabular}{lcccc}
\hline \multicolumn{1}{c}{ Habitat } & $\begin{array}{l}1^{\text {st }} \text { Dry } \\
\text { Season }\end{array}$ & $\begin{array}{l}1^{\text {st }} \text { Rain } \\
\text { Season }\end{array}$ & $\begin{array}{c}2^{\text {nd }} \text { Dry } \\
\text { Season }\end{array}$ & $\begin{array}{c}2^{\text {nd }} \text { Rain } \\
\text { Season }\end{array}$ \\
\hline $\begin{array}{l}\text { Chena } \text { and Rain Fed } \\
\text { Vegetables }\end{array}$ & Avoid & Indif & Avoid & Indif \\
$\begin{array}{l}\text { Forest } \\
\text { Grassland }\end{array}$ & Indif & Indif & Indif & Indif \\
Human Habitats & Pref & Avoid & Pref & Avoid \\
Paddy Cultivations & Avoid & Avoid & Avoid & Avoid \\
Rocks & Avoid & Avoid & Avoid & Avoid \\
Scrub Land & Avoid & Indif & Avoid & Indif \\
Water bodies & Indif & Indif & Indif & Indif \\
\hline No: Avoif & Avoid & Avoid & Indif & Avoid \\
\hline
\end{tabular}

Note: Avoid = Avoiding, Indif = Indifferent, Pref= Preferred 
Site 1 (North Central Region

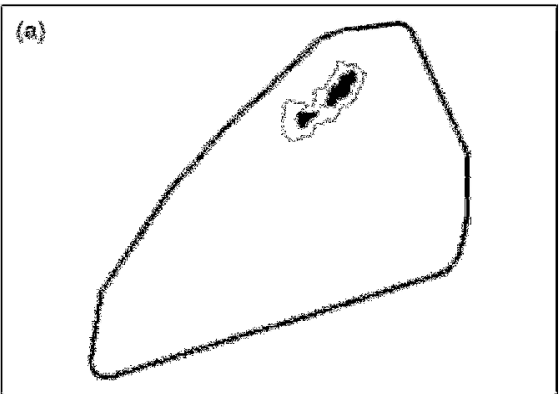

Site 2 (Southern Region)

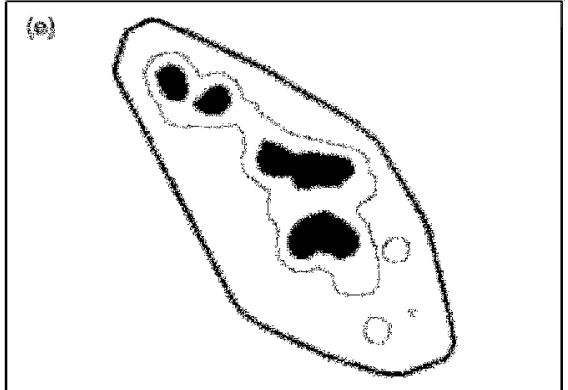

season

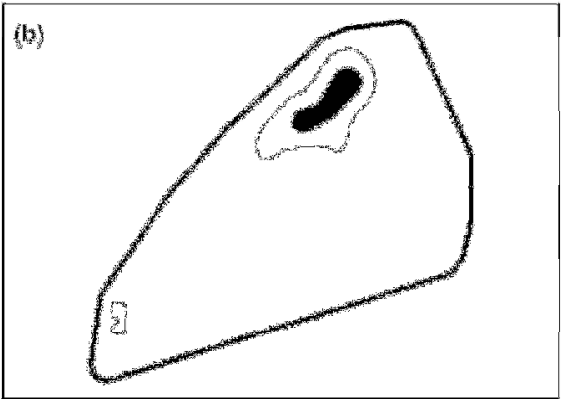

桨售

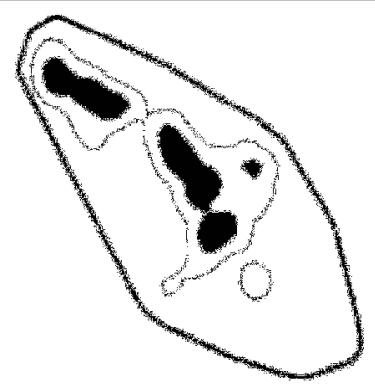

ist Wet Season

(c)

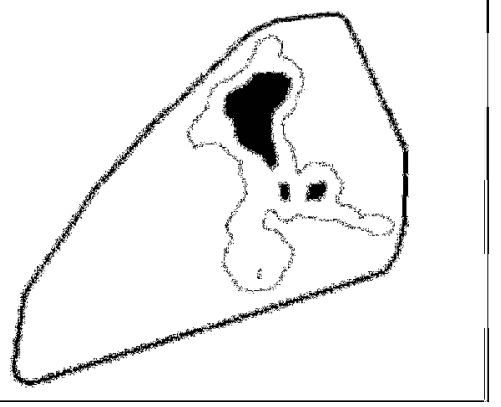

(a)

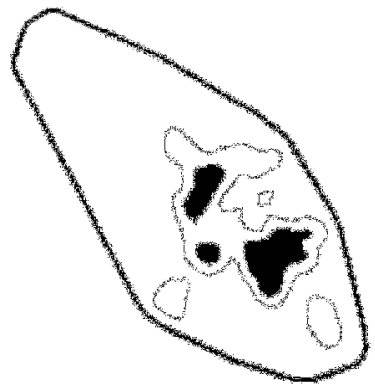

2nd Dory ssestan
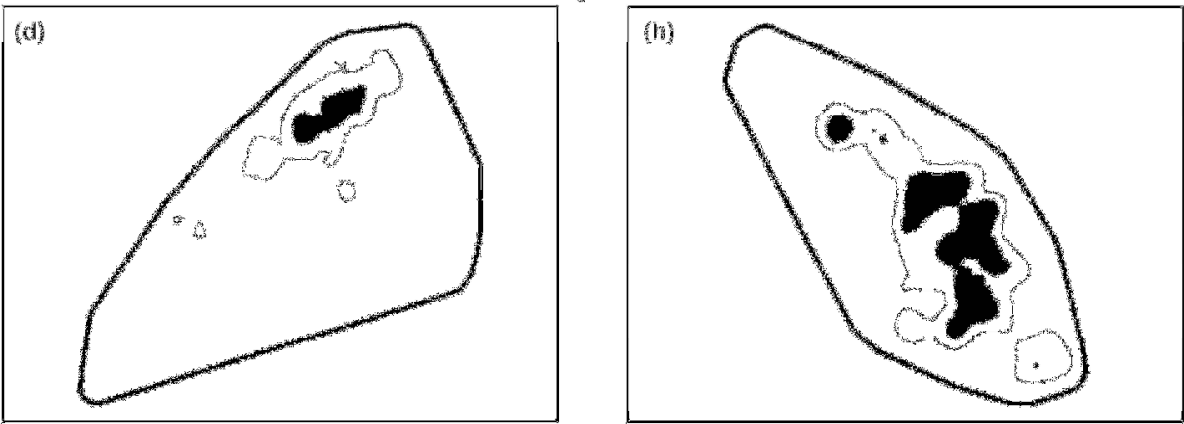

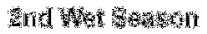

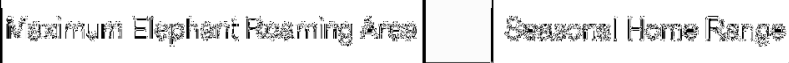

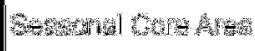

Fig. 2. Seasonal change of the home ranges of elephants in two study sites 
Table 5. Jacob's Index values for the $2^{\text {nd }}$ site

\begin{tabular}{lrrrr}
\hline \multicolumn{1}{c}{ Habitat } & \multicolumn{1}{c}{$\begin{array}{c}\text { st } \\
\text { Season }\end{array}$} & $\begin{array}{l}\mathbf{1}^{\text {st }} \text { Rain } \\
\text { Season }\end{array}$ & \multicolumn{1}{c}{$\begin{array}{c}\mathbf{2}^{\text {nd }} \text { Dry } \\
\text { Season }\end{array}$} & \multicolumn{1}{c}{$\begin{array}{c}\mathbf{2}^{\text {nd }} \text { Rain } \\
\text { Season }\end{array}$} \\
\hline Chena and Rain Fed Vegetables & -0.0761 & -0.0692 & -0.0001 & -0.0171 \\
Forest & 0.0878 & 0.1042 & -0.0671 & -0.1095 \\
Grassland & $\mathrm{NA}$ & $\mathrm{NA}$ & $\mathrm{NA}$ & $\mathrm{NA}$ \\
Human Habitats & -0.6560 & -0.4184 & -0.4569 & -0.5556 \\
Paddy Cultivations & -0.4318 & -0.3889 & -0.3834 & -0.3777 \\
Rocks & -0.3529 & -1.0000 & 0.1216 & -0.3308 \\
Scrub Land & 0.1541 & 0.0944 & 0.1875 & 0.2204 \\
Water bodies & -0.3691 & -0.1833 & -0.4220 & -0.3610 \\
\hline
\end{tabular}

Table 6. Selection of habitats by elephants in the $2^{\text {nd }}$ Site

\begin{tabular}{lcccc}
\hline \multicolumn{1}{c}{ Habitat } & $\begin{array}{c}\mathbf{1}^{\text {st }} \text { Dry } \\
\text { Season }\end{array}$ & $\begin{array}{c}\mathbf{1}^{\text {st }} \text { Rain } \\
\text { Season }\end{array}$ & $\begin{array}{c}\mathbf{2}^{\text {nd }} \text { Dry } \\
\text { Season }\end{array}$ & $\begin{array}{c}\mathbf{2}^{\text {nd }} \text { Rain } \\
\text { Season }\end{array}$ \\
\hline Chena and Rain Fed Vegetables & Indif & Indif & Indif & Indif \\
Forest & Indif & Indif & Indif & Indif \\
Grassland & $N A$ & $N A$ & $N A$ & $N A$ \\
Human Habitats & Avoid & Avoid & Avoid & Avoid \\
Paddy Cultivations & Avoid & Avoid & Avoid & Avoid \\
Rocks & Avoid & Avoid & Indif & Avoid \\
Scrub Land & Indif & Indif & Indif & Indif \\
Water bodies & Avoid & Indif & Avoid & Avoid \\
\hline
\end{tabular}

Note: Avoid $=$ Avoiding, Indif = Indifferent, Pref $=$ Preferred, $N A=$ Not Available

Table 7. Attributes and calculated values for the $1^{\text {st }}$ site

\begin{tabular}{|c|c|c|c|c|c|c|c|}
\hline Habitat & TFX & $\mathrm{AHC}_{\mathrm{AOI}}{ }^{1}$ & $\mathbf{R A}_{\mathrm{AOI}}$ & $\mathbf{U}_{\mathbf{E}}$ & $\mathbf{U}_{\mathbf{A}}$ & $\mathbf{U}_{\mathbf{P E}}$ & $\mathbf{U}_{\mathbf{P A}}$ \\
\hline Chena and Rain Fed Vegetables & 67 & 56.23 & 0.172 & 480.5 & 67 & 0.18 & 0.02 \\
\hline Forest & 643 & 96.17 & 0.294 & 821.7 & 643 & 0.29 & 0.23 \\
\hline Grassland & 3 & 0.32 & 0.001 & 2.7 & 3 & 0.00 & 0.00 \\
\hline Human Habitats & 1 & 11.27 & 0.034 & 96.3 & 1 & 0.04 & 0.00 \\
\hline Paddy Cultivations & 3 & 7.74 & 0.024 & 66.1 & 3 & 0.02 & 0.00 \\
\hline Rocks & 0 & 0.30 & 0.001 & 2.6 & 0 & 0.00 & 0.00 \\
\hline Scrub Land & 2047 & 139.08 & 0.425 & 1188.4 & 2047 & 0.46 & 0.73 \\
\hline Water bodies & 32 & 16.12 & 0.049 & 137.7 & 32 & 0.05 & 0.01 \\
\hline Total & 2796 & 327.2 & & & & & \\
\hline
\end{tabular}


Table 8. Expected values and confidence intervals of the $1^{\text {st }}$ site

\begin{tabular}{|c|c|c|c|c|}
\hline \multirow[t]{2}{*}{ Habitat } & \multirow[t]{2}{*}{$\mathbf{U}_{\mathbf{P E}}$} & \multirow[t]{2}{*}{$\mathbf{U}_{\mathbf{P A}}$} & \multicolumn{2}{|c|}{ Confidence Interval (CI) } \\
\hline & & & Left & Right \\
\hline Chena and Rain Fed Vegetables ${ }^{1}$ & 0.18 & 0.02 & 0.01604 & 0.03189 \\
\hline Forest $^{1}$ & 0.29 & 0.23 & 0.20817 & 0.25178 \\
\hline Grassland $^{2}$ & 0.00 & 0.00 & -0.00062 & 0.00277 \\
\hline Human Habitats ${ }^{1}$ & 0.04 & 0.00 & -0.00062 & 0.00134 \\
\hline Paddy Cultivations ${ }^{1}$ & 0.03 & 0.00 & -0.00062 & 0.00277 \\
\hline Rocks $^{0}$ & 0.00 & 0.00 & 0.00000 & 0.00000 \\
\hline Scrub Land ${ }^{2}$ & 0.46 & 0.73 & 0.70917 & 0.75507 \\
\hline Water bodies ${ }^{1}$ & 0.05 & 0.01 & 0.00593 & 0.01696 \\
\hline
\end{tabular}

Note: $1=\mathrm{CI}$ is below $\mathrm{U}_{\mathrm{PE}}-$ the habitat is avoided, $2=\mathrm{CI}$ is above the $\mathrm{U}_{\mathrm{PE}}-$ habit is preferred, $0=\mathrm{U}_{\mathrm{PE}}$ is within $\mathrm{CI}_{-}$Indifferent.

Table 9. Attributes and calculated values for the $2^{\text {nd }}$ site

\begin{tabular}{|c|c|c|c|c|c|c|c|}
\hline Habitat & TFX & $\mathrm{AHC}_{\mathrm{AOI}}{ }^{1}$ & $\mathbf{R} \mathbf{A}_{\mathrm{AOI}}$ & $\mathbf{U}_{\mathbf{E}}$ & $\mathbf{U}_{\mathbf{A}}$ & $\mathbf{U}_{\mathbf{P E}}$ & $\mathbf{U}_{\mathbf{P A}}$ \\
\hline $\begin{array}{l}\text { Chena and Rain } \\
\text { Fed Vegetables }\end{array}$ & 602 & 32.11 & 0.148 & 558.2 & 602 & 0.15 & 0.16 \\
\hline Forest & 720 & 32.88 & 0.151 & 571.6 & 720 & 0.15 & 0.19 \\
\hline Grassland & & NA & NA & NA & NA & NA & NA \\
\hline Human Habitats & 20 & 9.78 & 0.045 & 170.1 & 20 & 0.05 & 0.01 \\
\hline $\begin{array}{l}\text { Paddy } \\
\text { Cultivations }\end{array}$ & 38 & 6.09 & 0.028 & 105.9 & 38 & 0.03 & 0.01 \\
\hline Rocks & 1 & 0.18 & 0.001 & 3.1 & 1 & 0.00 & 0.00 \\
\hline Scrub Land & 2203 & 124.99 & 0.576 & 2173.0 & 2203 & 0.58 & 0.58 \\
\hline Water bodies & 191 & 11.11 & 0.051 & 193.1 & 191 & 0.05 & 0.05 \\
\hline Total & 3775 & 217.14 & & & & & \\
\hline
\end{tabular}

${ }^{1}$ Area in hectares $1253.346, \chi^{2}$ Calculated $=219.8, \chi^{2}$ Table $=12.59(\alpha=05, \mathrm{df}=6)$

Table 10. Expected values and confidence intervals of the $2^{\text {nd }}$ site

\begin{tabular}{|c|c|c|c|c|}
\hline \multirow[b]{2}{*}{ Habitat } & \multirow[b]{2}{*}{$\mathbf{U}_{\mathbf{P E}}$} & \multirow[b]{2}{*}{$\mathbf{U}_{\mathbf{P A}}$} & \multicolumn{2}{|c|}{ Confidence Interval (CI) } \\
\hline & & & Left & Right \\
\hline Chena and Rain Fed Vegetables ${ }^{0}$ & 0.15 & 0.16 & 0.14338 & 0.17556 \\
\hline Forest $^{2}$ & 0.15 & 0.19 & 0.17346 & 0.20799 \\
\hline Grassland & NA & NA & NA & NA \\
\hline Human Habitats ${ }^{1}$ & 0.05 & 0.01 & 0.00211 & 0.00849 \\
\hline Paddy Cultivations ${ }^{1}$ & 0.03 & 0.01 & 0.00568 & 0.01445 \\
\hline Rocks $^{0}$ & 0.00 & 0.00 & -0.00045 & 0.00098 \\
\hline Scrub Land ${ }^{0}$ & 0.58 & 0.58 & 0.56191 & 0.60524 \\
\hline Water bodies $^{0}$ & 0.05 & 0.05 & 0.04096 & 0.06023 \\
\hline
\end{tabular}


The outcome of the Bonferroni's CI procedure was used to compare two sites (Table 11). According to the outcome, Chena is an avoided land use in the North-Central herd and it was used indifferently in the Southern Region elephants. Forest was an avoided land use in the North-Central Region and it was a preferred landscape in the Southern Region. Grassland was a preferred land use in North-Central Region. However, such grasslands were unavailable in the Southern region site. Human habitats and paddy cultivation are avoided land uses. Rocky terrains are indifferent in both cases.

Table 11. Comparison of study sites using Bonferroni's CI procedure

\begin{tabular}{lcc}
\hline \multicolumn{1}{c}{ Habitat } & North-Central Region & Southern Region \\
\hline Chena and Rain Fed Vegetables & Avoided & Indifferent \\
Forest & Avoided & Preferred \\
Grassland & Preferred & $N A$ \\
Human Habitats & Avoided & Avoided \\
Paddy Cultivations & Avoided & Avoided \\
Rocks & Indifferent & Indifferent \\
Scrub Land & Preferred & Indifferent \\
Water bodies & Avoided & Indifferent \\
\hline
\end{tabular}

According to the analysis (Table 4 and Table 6), even though grasslands are available only in the site 1 they are preferred in dry season and avoided in the wet season. According to this behaviour it is apparent that the grasslands area capable in providing necessities for elephants even in dry season compared to other habitat types. In site 2 no grasslands were present and there is no specially preferred land use type in the site. Therefore, grasslands can assume to be a preferred land use type in general. The avoidance of grasslands in the wet season may be due to increased food availability in the other land use type during wet season making elephants to stay in the areas such as forests where safety is high. According to Bonferroni's CI Procedure (Table 11) it was shown that Grasslands and Scrub Land area preferred land use types. Forests were not preferred in the site 2 where no grasslands available. In this context, developing management interventions on human elephant conflict mitigation, grasslands and scrublands are the primary areas to be focused on and conservation of forests is the next.

According to the results of the study, human habitations and paddy cultivations are avoided by the elephants (Table 11). However, Human Elephant Conflict occurs mostly when elephants invaded into such areas. Past studies (Campos-Arceiz et al., 2009) suggested that Human Elephant Conflicts increase during dry seasons. The results of this study have shown that the extent of the core use area does not change much with the seasons. However, the seasonal habitats increase in extent during dry seasons. Hence, one can infer that the elephants try to invade into human habitations and cultivations during dry seasons although it is an avoided area. The food availability both in quality and quantity is higher in human habitations and paddy cultivations and the harvesting is also relatively easy compared to other land use types. In such a context the reason/s for avoiding human habitations and paddy cultivations during any season, is an important question to be answered. Except all other habitats, human habitations and cultivations are heavily guarded by the community and 
the government organizations. In this scenario, movement in to such other habitats is purely voluntary while movement in to human habitation is affected by the protective measures and management interventions of the people and the government.

\section{CONCLUSIONS}

According to the results of the study it can be concluded that, although elephants tend to move in larger areas ranging from $29.6-346 \mathrm{~km}^{2}$ as reported earlier, the studied two herds use relatively small home range of about $75 \mathrm{~km}^{2}(72.97-73.07)$. Further, the two herds use relatively small core area of $21.62-25.76 \mathrm{~km}^{2}$ compared to the reported size of $40 \mathrm{~km}^{2}$ in earlier studies.

The maximum seasonal home range was shown during the dry season although water bodies were not the preferred land use types of the elephants. Water is a vital factor for life, but elephants do not spend much time in the water. Even during the dry season, water bodies are not preferred land use class. Therefore, the main problem for elephants in long and stronger dry season may be the inadequacy of food comparative to the scarcity of water. Therefore, if the home range of the elephants needed to be restricted to a small area for management requirements such as minimizing elephant human conflict, constructing water bodies inside the forests would not be an ideal solution. In this context, habitat enrichment to make food available is the most viable option. Out of the total area of the home range, the core area should be given priority.

The total area explored by the elephant in the North-Central herd $\left(327.2 \mathrm{~km}^{2}\right)$ was higher than the Southern herd $\left(217.1 \mathrm{~km}^{2}\right)$. However, the seasonal home range and the seasonal core home ranges of the Southern region elephants are high. The most possible reason may be the quality of the habitat. When examine the quality of the habitat of the North-Central herd, the area is rich in food compared to the area of the Southern herd. The area of the Southern herd is more disturbed and degraded than that of the North-Central herd.

The study has shown the ability of geo-informatics in evaluating the preference of different habitat types during different seasons by the elephants. In planning elephant related management activities, these findings and the procedures could be used effectively. Managed elephant reserves are the most recent management intervention to minimize the human elephant conflict. Management of "Managed Elephant Reserves", enrichment of the elephant habitats, and "protection-infrastructure" (i.e. Electric fences) establishment which restrict the movement of elephants should be done after identifying the core use areas as presented in this paper.

\section{ACKNOWLEDGEMENT}

The authors would like to acknowledge the financial support provided by the National Research Council of Sri Lanka through grant No. 12-098 to carry out this study. The telemetry data and other assistance provided by the Department of Wildlife Conservation and its staff are also greatly appreciated. 


\section{REFERENCES}

Arceiz, A.C., Takatsuk, S., Ekanayaka, S.K.K. and Hasegawa, T. (2009). The HumanElephant Conflict in South-eastern Sri Lanka: Type of Damage, Seasonal Patterns, and Sexual Differences in the Raiding Behaviour of Elephants. Gajah, 31, 5 - 14.

Bandara, R. (2005). The Economics of Human-Elephant Conflict. Ministry of Environment and Natural Resources, Colombo, Sri Lanka.

Baskaran, N., Balasubramanian, S., Swaminathan, S. and Desai, A. (1995). Ranging behaviour of elephants and its implication for the management of Nilgiri biosphere Reserve, India. Proceedings of the International Seminar on the Conservation of Asian Elephant. Mudumalai Wildlife Sanctuary.

Borger, L., Franconni, N., de Michele, G., Gantz, A., Meschi, F. and Manica, A. (2006). Effects of sampling regime on the mean and variance of home range size estimates, J. Anim. Ecol. 75, 1393 - 1405.

Byers, C., Steinhorst, R., and Krausman, P. (1984).Clarification of a technique for analysis of utilization-availability data. J. Wild. Manage., 48, 1050 - 1053.

Campos-Arceiz, A. Takatsuki, S. Ekanayaka, S. and Hasegawa, T. (2009). The HumanElephant Conflict in South-eastern Sri Lanka: Type of Damage, Seasonal Patterns, and Sexual Differences in the Raiding Behaviour of Elephants. Gajah, 31, 5 - 14.

De Boer, W. and Baquete, D. (1998).Natural resource use, crop damage and attitudes of rural people in the vicinity of MER, Mozambique.Env.Conserv.,25, 208 - 218.

De Silva, R. and Punyawardena, B.V.R. (2006). Characterization of heavy rain and subsequent dry periods during North-East monsoon in the dry zone of Sri Lanka. J. Natn.Sci. Foundation Sri Lanka, 34(3), 159 - 161.

Department of Wildlife Conservation. (2013). The First Island-wide National Survey of Elephants In Sri Lanka - 2011. Department of Wildlife Conservation, Colombo.

Desi, A. (1998). The Conservation of Elephants and Human-Elephant Conflict in Sri Lanka. Department of Wildlife Conservation. Colombo, Sri Lanka.

Fernando, P., Jayewardene, J., Prasad, T. and Hendavitharana, W. (2011).Current Status of Asian Elephants in Sri Lanka. Gajah, 35, 93 - 103.

Jacobs, J. (1974). Quantitative measurement of food selection.Ecologia, 14, 413 - 417.

Jakson, T. and Erasmus, D. (2005).Assessment of Seasonal Homerange Use by Elephants across Southern Africa's Seven Elephant Clusters.Conservation Ecology Research Unit.University of Pretoria, Pretoria.

Krieger, F., Malila, W., Nalepka, R. and Richardson, W. (1969). Preprocessing transformations and their effects on multispectral recognition.Sixth International Symposium on Remote Sensing of Environment University of Michigan, Michigan, pp. 97-131. 
Natumi, C. (2002). Space and habitat use by elephants (Loxodonta africana) in the Maputo Elephant Reserve, Mozambique. University of Pretoria, Pretoria.

Natumi, C., van Aarde, R., Fairall, N. and de Boer, W. (2005).Use of space and habitat by elephants (Loxodontaafricana) in the Maouto Elephant Reserve, Mozambique. South African Journal of Wildlife Research, 35(2), 139 - 146.

Neu, C., Byers, C. and Peek, J. (1974).A technique for analysis of utilization-availability data. J. Wildl. Manage., 38, 541 - 545.

Roux, C. and Bernard, R. (2007).Home range size, spatial distribution and habitat use of elephants in two enclosed game reserves in the Eastern Cape Province, South Africa. Afr. J. Ecol., 47, 146 - 152.

Santiapillai, C. and De Silva, M. (1994). An Action Plan for the Conservation and Management of Elephant (Elephas maximus) in Sri Lanka. Gajah, 13, 1 - 24.

Weerakoon, D., Gunawardene, M., Janaka, H., Jayasinghe, L., Perera, R., Fenando, P. andWickramanayake, E. (2003). Ranging BehaviourAnd Habitat Use of Elephants in Sri Lanka. Proceedings of the Symposium for Human-Elephant Relationships and Conflicts. Biodiversity and Elephant Conservation Trust, Colombo. pp. 68-70.

Western, D. and Lindsay, K. (1984).Seasonal herd dynamics of a savannah elephant population. Afr. J. Ecol., 22, 229 - 224.

Worton, B. (1989). Kernel methods for estimating the utilization distribution in home range studies. Ecology, 70, 164 - 168. 